\title{
Pengaruh Implementasi Model Creative Problem Solving terhadap Peningkatan Kemampuan Pemecahan Masalah, Keterampilan Proses Sains, dan Kesadaran Metakognisi Peserta Didik
}

\author{
Muhali \\ Program Studi Pendidikan Kimia, Fakultas Sains, Teknik, dan Terapan, Universitas \\ Pendidikan Mandalika, Indonesia \\ Corresponding Author Email: muhali@undikma.ac.id
}

Sejarah Artikel

Dikirim: April 2021

Diterima: May 2021

Dipublikasi: June 2021

\section{Kata Kunci}

Creative Problem Solving;

Problem Solving;

Kemampuan Pemecahan

Masalah; Keterampilan

Proses Sains; Kesadaran

Metakognisi

\begin{abstract}
Abstrak
Penelitian ini bertujuan mengetahui pengaruh peningkatan kemampuan pemecahan masalah, keterampilan proses sains, dan kesadaran metakognisi peserta didik melalui pembelajaran model creative problem solving. Metode dalam penelitian ini menggunakan quasi eksperimen dengan pretest-posttest control group design. Sampel terdiri dari 58 peserta didik kelas XI IPA SMAN 1 Praya Timur yang ditentukan menggunakan teknik sampel jenuh. Instrumen yang digunakan berupa tes kemampuan pemecahan masalah, lembar penilaian keterampilan proses sains, dan angket kesadaran metakognisi yang telah dinyatakan valid dan reliabel. Analisis data dilakukan menggunakan uji t dengan bantuan SPSS 16.0 for windows. Hasil penelitian menunjukkan bahwa (1) kemampuan pemecahan masalah $(0,693>0,403)$; (2) keterampilan proses sains $(0,369>0,094)$; dan (3) kesadaran metakognisi $(0,532>0,474)$ kelompok eksperimen lebih baik dibandingkan dengan kelompok kontrol baik secara deksriptif maupun statistik $(p<0,05)$, sehingga dapat disimpulkan bahwa model creative problem solving berpengaruh terhadap peningkatan kemampuan pemecahan masalah, keterampilan proses sains, dan kesadaran metakognisi peserta didik dalam pembelajaran kimia materi hidrolisis garam.
\end{abstract}

\section{Implementation of the Creative Problem Solving Model to Improve Problem Solving Ability, Science Process Skills, and Metacognition Awareness of Learners}

\section{Article History \\ Received: April 2021 \\ Accepted: May 2021 \\ Published: June 2021}

\section{Key Words}

Creative Problem Solving;

Problem Solving; Problem

solving skill; Science Process

Skills; Metacognitive

Awareness

How to cite this article?

\begin{abstract}
This study aims to determine the effect of creative problem solving learning model on students' problem solving abilities, science process skills, and metacognitive awareness. The method in this study uses a quasi-experimental with pretest-posttest control group design. The sample consisted of 58 students of class XI IPA SMAN 1 Praya Timur who were determined using the saturated sample technique. The instruments used were in the form of a problem-solving ability test, a science process skill assessment sheet, and a metacognition awareness questionnaire which had been declared valid and reliable. Data analysis was performed using t test with the help of SPSS 16.0 for windows. The results showed that (1) problem solving ability $(0.693>0.403)$; (2) science process skills $(0.369>0.094)$; and (3) metacognitive awareness $(0.532>0.474)$ the experimental group was better than the control group both descriptively and statistically $(p<0.05)$, so it can be concluded that the creative problem solving model has an effect on increasing problem solving abilities, science process skills, and students' metacognition awareness in learning chemistry of salt hydrolysis material.
\end{abstract}

Muhali, M. (2021). Pengaruh Implementasi Model Creative Problem Solving terhadap Peningkatan Kemampuan Pemecahan Masalah, Keterampilan Proses Sains, dan Kesadaran Metakognisi Peserta Didik. Lensa: Jurnal Kependidikan Fisika, 9(1), 45-57. doi:https://doi.org/10.33394/j$\underline{1 \mathrm{kf} . v 9 i 1.4261}$ 


\section{PENDAHULUAN}

Mempelajari dan memahami ilmu kimia dapat dilakukan melalui aspek representasi secara makroskopik, mikroskopik, dan simbolik. Representasi secara makroskopik dapat berupa fenomena yang terjadi pada kehidupan sehari-hari maupun dalam laboratorium yang dapat diamati langsung. Representasi mikroskopik memiliki tingkatan untuk menjelaskan dan menerangkan fenomena yang diamati sehingga menjadi sesuatu yang dapat dipahami, representasi ini lebih menekankan pada partikel dan sifatnya. Representasi simbolik digunakan untuk mewakili fenomena makroskopik dapat menggunakan persamaan kimia, persamaan matematika, grafik, maupun mekanisme reaksi. Oleh karena itu, ketiga representasi tersebut penting disajikan dalam pembelajaran kimia agar peserta didik dapat belajar dan terlatih memecahkan masalah, melibatkan keterampilan proses sains dalam melakukan kegiatan percobaan, dan metakognisi. Menurut Jefriadi et al. (2014) memahami konsep kimia secara utuh dapat terjadi pada peserta didik dengan memberikan atau menyajikan ketiga representasi kimia dalam pembelajaran secara terintegrasi dan proporsional.

Kemampuan pemecahan masalah, keterampilan proses sains, dan kesadaran metakognisi merupakan tiga aspek penting untuk dilatih dan dibelajarkan secara terusmenerus dalam pembelajaran sains. Ciri utama proses pemecahan masalah adalah berkaitan dengan masalah-masalah yang tidak rutin (Muhali, 2018). Secara garis besar langkah utama dalam pemecahan masalah yaitu: (1) understanding the problem, (2) devising a plan, (3) carrying out the plan, dan (4) looking back (Polya, 1957). Kemampuan pemecahan masalah merupakan suatu tingkatan aktivitas intelektual yang tinggi, peserta didik didorong dan diberi kesempatan seluas-luasnya untuk berinisiatif dan berpikir sistematis dalam menghadapi sutau masalah dengan menerapkan pengetahuan yang didapat sebelumnya. Menurut Prayogi et al. (2014), keterampilan proses intelektual yang diharapkan dalam pembelajaran yang berorientasi pada sains adalah: (1) membangun prinsip melalui induksi, (2) menjelaskan dan meramalkan, (3) pengamatan dan mencatat data, (4) identifikasi dan mengendalikan variabel, (5) membuat grafik untuk menemukan hubungan, (6) perancangan dan melaksanakan penyelidikan ilmiah, (7) menggunakan teknologi dan matematika selama penyelidikan, dan (8) menggambarkan simpulan dari bukti-bukti. Keterampilan proses sains sangat penting untuk dilatihkan kepada peserta didik untuk menghadapi tantangan dalam kehidupan yang bertambah kompleks sekarang ini. Oleh karena itu, seorang guru harus membuat berbagai interaksi dan pengalaman belajar serta pengetahuan tentang proses-proses ilmiah dalam pengkonstruksian informasi baru dan pemecahan masalah sehingga dapat menarik perhatian dan memudahkan peserta didik mengembangkan keterampilan proses sains. Kesadaran metakognisi melibatkan pengetahuan tentang kognisi dan pengetahuan tentang regulasi kognisi (Muhali, 2018). Pengetahuan tentang kognisi meliputi pengetahuan deklaratif, pengetahuan prosedural, dan pengetahuan kondisional, sedangkan pengetahuan tentang regulasi kognisi meliputi perencanaan, monitoring, strategi manajemen informasi, perbaikan strategi, dan evaluasi (Muhali et al., 2019). Pengajaran konsep sains menuntut peserta didik untuk terampil menyelesaikan setiap permasalahan pembelajaran melalui serangkaian keterampilan proses untuk mendapatkan pengetahuan dan regulasi secara utuh.

Berbagai implementasi model pembelajaran yang membelajarkan peserta didik pada ketiga aspek di atas. Sukaisih \& Muhali (2014); dan Sukaisih et al. (2020) membelajarkan metakognisi dengan menggunakan model problem solving dan integrasinya dengan strategi konflik kognitif, secara umum pengetahuan dan reguluasi metakognisi tetapi pada aspek regulasi metakognisi peserta didik masih mendapatkan kesulitan dalam kemampuan mengevaluasi dan memperbaiki strategi penyelesaian masalah secara benar. Hasil ini 
terjadi karena dalam implementasinya model problem solving peserta didik tidak dapat melihat kembali proses pemecahan masalah dengan baik (looking back) sesuai tahap pemecahan masalah menurut Polya (1957). Oleh karena itu, peserta didik perlu dilatih dan diarahkan untuk dapat melaksanakan tahap tersebut melalui pembelajaran yang menekankan pada langkah-langkah atau proses melihat kembali proses pemecahan masalah agar pengetahuan dan regulasi metakognisi dapat diimplementasikan dalam pembelajaran. Sagita et al. (2018) membelajarkan kemampuan metakognitif peserta didik melalui model problem solving, dan secara umum pada setiap indikator kemampuan metakognitif mengalami peningkatan, tetapi peserta didik dalam kemampuan menghubungkan pemahaman konseptual dengan pengalaman prosedural masih tergolong rendah. Kadaritna (2014) menerapkan model problem solving dalam meningkatkan keterampilan proses sains, dan hasilnya indikator seperti keterampilan prediksi, mengelompokkan, dan mengkomunikasikan mencapai kategori baik, sedangkan indikator keterampilan memprediksi masih tergolong kurang baik dibandingkan indikator yang lain. Oleh karena itu, perlu diupayakan pembelajaran yang mengarahkan peserta didik untuk dapat menyelesaikan masalah secara kreatif dan reflektif serta memungkinkan terjadinya pengintegrasian indikator-indikator kemampuan pemecahan masalah, keterampilan proses sains, dan kesadaran metakognisi dalam proses pembelajaran.

CPS sebagai model pembelajaran yang melakukan pemusatan pada pengajaran dan keterampilan memecahkan masalah. Peserta didik dapat melibatkan keterampilan memecahkan masalah dalam memilih dan mengembangkan tanggapannya. Keterampilan memecahkan masalah dapat memperluas proses berpikir, tidak hanya dengan cara menghafal tanpa berpikir (Shoimin, 2014). Model CPS juga merupakan variasi pembelajaran pemecahan masalah melalui teknik sistematik dalam mengorganisasikan gagasan kreatif untuk menyelesaikan permasalahan (Suyatno, 2009). Langkah-langkah model pembelajaran CPS (Shoimin, 2014) adalah sebagai berikut: (1) klarifikasi masalah, meliputi pemberian penjelasan kepada peserta didik tentang masalah yang diajukan, agar dapat memahami tentang penyelesaian yang diharapkan, (2) brainstorming/pengungkapan pendapat, peserta didik dibebaskan untuk mengungkapkan pendapat tentang berbagai macam strategi penyelesaian masalah, (3) evaluasi dan pemilihan, setiap kelompok peserta didik mendiskusikan pendapat atau strategi yang cocok untuk menyelesaikan masalah, (4) implementasi, peserta didik menentukan strategi yang dapat diambil untuk menyelesaikan masalah, menerapkannya sampai menemukan penyelesaian dari masalah tersebut. Model CPS yang diimplementasikan dalam pembelajaran memiliki kelebihan dapat memberikan kesempatan peserta didik memahami konsep dengan cara menyelesaikan suatu masalah, membuat peserta didik aktif dalam pembelajaran, mengembangkan kemampuan berpikir dan membuat peserta didik dapat menerapkan pengetahuan yang telah dimilikinya (Totiana et al., 2013). Model CPS juga menjadikan peserta didik berperan aktif dalam pembelajaran dan secara kreatif berusaha menemukan solusi dari permasalahan yang diajukan, saling berinteraksi dengan sesamanya maupun dengan guru, saling bertukar pikiran, sehingga wawasan dan daya piker peserta didik berkembang dan menyedari banyak hal atau kejadian yang ditemukan dalam kehidupan sehari-hari (Hariawan et al., 2014).

Salah satu materi kimia yang dipelajari peserta didik kelas XI SMA adalah hidrolisis garam. Materi ini mengkaji tentang reaksi ionisasi garam yang terlarut dalam air, yang tentu tidak dapat dilihat secara kasat mata. Gejala atau fakta yang dapat diamati peserta didik adalah nilai $\mathrm{pH}$ larutan garam melalui kegiatan percobaan. Pengamatan terhadap fakta yang diperoleh dari percobaan diharapkan peserta didik dapat menemukan konsep tentang hidrolisis garam secara mandiri menggunakan keterampilan proses sains yang secara sistematis dan disadari dalam memecahkan masalah melalui pembelajaran model 
CPS. Beberapa peneliti sebelumnya menyakini bahwa implementasi model CPS dapat meningkatkan kemampuan pemecahan masalah (Sagita et al., 2018), keterampilan proses sains (Bakar et al., 2018; Fitriah, 2013; Sumarli et al., 2018), dan kesadaran metakognisi (Effendi, 2016).

Berdasarkan uraian tersebut maka mumusan masalah pada penelitian ini yaitu bagaimanakah peningkatan kemampuan pemecahan masalah, keterampilan proses sains, dan kesadaran metakognisi peserta didik dalam pembelajaran kimia melalui penerapan model CPS? Tujuan yang diharapkan dapat dicapai dari penelitian ini yaitu implementasi model CPS dapat meningkatkan kemampuan pemecahan masalah, keterampilan proses sains, dan kesadaran metakognisi peserta didik dalam pembelajaran kimia materi hidrolisis garam

\section{METODE}

Jenis penelitian yang digunakan adalah penelitian quasi eksperimen, dengan rancangan pretest-posttest control group design (Arikunto, 2013) seperti disajikan pada Tabel 1 berikut ini.

Tabel 1. Rancangan Penelitian Pretest-Posttest Control Group Design

\begin{tabular}{lccc}
\hline \multicolumn{1}{c}{ Kelompok } & Pretest & Perlakuan & Posttest \\
\hline Eksperimen & $\mathrm{O}_{1}$ & $\mathrm{X}$ & $\mathrm{O}_{2}$ \\
Kontrol & $\mathrm{O}_{2}$ & $\mathrm{Y}$ & $\mathrm{O}_{4}$ \\
\hline
\end{tabular}

Keterangan:

$\mathrm{X}$ : Perlakuan kelompok eksperimen dengan menggunakan model pembelajaran CPS (Creative Problem Solving).

Y : Perlakuan kelompok kontrol dengan menggunakan model pembelajaran PS (Problem Solving).

$\mathrm{O}_{1}$ : Pretest pada kelompok eksperimen sebelum diberikan perlakuan.

$\mathrm{O}_{2}$ : Posttest yang diberikan pada kelompok eksperimen setelah perlakuan dengan pembelajaran model CPS.

$\mathrm{O}_{3}$ : Pretest pada kelompok kontrol sebelum diberikan perlakuan.

$\mathrm{O}_{4}$ : Posttest yang diberikan pada kelompok kontrol setelah perlakuan dengan pembelajaran model PS.

Populasi pada penelitian ini sebanyak 58 orang peserta didik kelas XI IPA SMAN 1 Praya Timur yang terbagi ke dalam 2 (dua) kelas paralel, yaitu kelas XI IPA1 dengan jumlah peserta didik 31 orang dan kelas IPA2 sebanyak 27 orang. Kedua kelas tersebut selanjutnya dijadikan sebagai sampel penelitian (menggunakan teknik sampling jenuh). Penentuan kelompok eksperimen dan kontrol dilakukan dengan mengundi kedua kelas sampel tersebut, dan diperoleh kelas XI IPA2 sebagai kelompok eksperimen dan kelas XI IPA1 sebagai kelompok kontrol.

Instrumen pada penelitian ini menggunakan tes kemampuan pemecahan masalah, lembar penilaian keterampilan proses sains, dan angket kesadaran metakognisi peserta didik. Instrument tes kemampuan pemecahan masalah berupa tes uraian materi hidrolisis garam sebanyak 9 (Sembilan) butir soal, Instrumen lembar penilaian keterampilan proses sains memuat aspek dan subaspek yang teramati pada saat pembelajaran berlangsung meliputi: (1) aspek keterampilan dasar; (a) keterampilan mengamati, (b) keterampilan mencatat/merekam data dan informasi, (c) keterampilan memahami/mengikuti perintah/instruksi, (d) keterampilan mengimplementasikan prosedur, teknik atau penggunaan peralatan, (2) aspek keterampilan mengolah/memproses; (a) keterampilan membuat prediksi, dan (b) keterampilan menginferensi/menyimpulkan, (3) aspek 
keterampilan menginvestigasi; (a) keterampilan merancang investigasi/eksperimen, dan (b) keterampilan melaksanakan investigasi/eksperimen. Instrumen tes kemampuan pemecahan masalah dan lembar penilaian keterampilan proses sains telah dilakukan uji kelayakan oleh validator ahli dan diperoleh bahwa sebesar $94,44 \%$ dan $84,09 \%$ indikator mencapai kategori sangat valid, sehingga kedua instrumen tersebut sangat layak digunakan dalam pembelajaran dengan model CPS untuk mengukur kemampuan pemecahan masalah dan keterampilan proses sains. Instrumen angket kesadaran metakognisi yang digunakan merupakan instrument MAI (metacognition awareness inventory) menurut Schraw \& Dennison (1994) yang diadaptasi oleh Muhali et al. (2019) dan telah diujicobakan serta dinyatakan valid dan reliabel. Instrumen tersebut terdiri dari 52 butir angket yang terbagi ke dalam 8 indikator yaitu: (1) pengetahuan deklaratif, (2) pengetahuan prosedural, (3) pengetahuan kondisional, (4) perencanaan, (5) memonitor, (6) strategi manajemen informasi, (7) perbaikan strategi, dan (8) evaluasi.

Teknik pengumpulan data pada penelitian ini yaitu: (1) teknik tes menggunakan soal uraian untuk mendapatkan data kemampuan pemecahan masalah, dilakukan sebelum dan setelah pembelajaran pada kedua kelompok peserta didik (eksperimen dan kontrol), (2) teknik penilaian kinerja untuk memperoleh data keterampilan proses sains, dilakukan dengan menilai setiap aspek keterampilan yang muncul pada setiap individu peserta didik saat pembelajaran berlangsung pada setiap pertemuan, dengan menggunakan lembar penilaian keterampilan proses sains, dan (3) teknik angket digunakan untuk memperoleh data kesadaran metakognisi, dilakukan dengan memberikan angket kesadaran metakognisi pada kedua kelompok peserta didik sebelum dan setelah pembelajaran.

Analisis data kemampuan pemecahan masalah dan keterampilan proses sains serta kesadaran metakognisi peserta didik dilakukan dengan menggunakan rumus sebagai berikut.

$$
\text { Nilai }=\frac{\text { jumlah skor }}{\text { skor maksimal }} \times 100
$$

Nilai dari kemampuan pemecahan masalah, keterampilan proses sains, dan kesadaran metakognisi yang diperoleh selanjutnya dikelompokkan ke dalam kriteria dan kategori sesuai Tabel 2 di bawah ini.

Tabel 2. Kriteria dan Kategori Kemampuan Pemecahan Masalah, Keterampilan Proses Sains, dan Kesadaran Metakognisi Peserta Didik

\begin{tabular}{cc}
\hline Nilai & Kategori \\
\hline $80-100$ & Sangat Tinggi \\
$66-79$ & Tinggi \\
$56-65$ & Cukup \\
$40-55$ & Rendah \\
$30-39$ & Sangat Rendah \\
\hline
\end{tabular}

Uji Normalized Gain (N-Gain) dilakukan untuk mengetahui peningkatan nilai sebelum dan setelah pembelajaran pada kedua kelompok peserta didik, dengan menggunakan rumus sebagai berikut.

$$
<G>=\frac{\text { Fpost }- \text { Fpre }}{100-\text { Fpre }}
$$

Keterangan: $\langle G\rangle=$ N-Gain, Fpost $=$ nilai posttest , dan Fpre $=$ nilai pretest .

Perolehan nilai N-Gain selanjutnya dikonversikan ke dalam kriteria seperti pada Tabel 3 berikut ini. 
Tabel 3. Nilai dan Kriteria Nilai N-Gain

\begin{tabular}{ccc}
\hline No. & Nilai & Kriteria \\
\hline 1 & $0,7-1,0$ & Tinggi \\
2 & $0,3-0,69$ & Sedang \\
3 & $0,0-0,29$ & Rendah \\
\hline
\end{tabular}

Data nilai kemampuan pemecahan masalah, keterampilan proses sains, dan kesadaran metakognisi yang telah dihsailkan selanjutnya dilakukan analisis statistika dengan bantuan SPSS 16.0 for windows.

\section{HASIL DAN PEMBAHASAN}

Penelitian ini dilakukan dengan tujuan untuk meningkatkan kemampuan pemecahan masalah, keterampilan proses sains, dan kesadaran metakognisi peserta didik melalui pembelajaran dengan mengimplementasikan model creative problem solving pada pembelajaran kimia materi hidrolisis garam. Data hasil penelitian yang diperoleh berupa data kemampuan pemecahan masalah, keterampilan proses sains, dan kesadaran metakognisi peserta didik pada kelompok eksperimen dan kelompok kontrol, selengkapnya dideskripsikan sebagai berikut.

\section{Kemampuan Pemecahan Masalah Peserta Didik}

Data kemampuan pemecahan masalah peserta didik diperoleh melalui pemberian tes uraian pada materi hidrolisis garam, dilakukan sebelum (pretest) dan setelah (posttest) pembelajaran pada kelompok eksperimen dan kontrol. Data kemampuan pemecahan masalah pada kelompok eksperimen sebelum pembelajaran yaitu sebanyak $7,41 \%$ peserta didik memperoleh nilai dengan kategori rendah, dan 92,59\% peserta didik memperoleh nilai dengan kategori sangat rendah, sedangkan data kemampuan pemecahan masalah setelah proses pembelajaran berlangsung dengan model CPS pada materi hidrolisis garam yaitu sebanyak $11,11 \%$ peserta didik memperoleh nilai dengan kriteria sangat tinggi, sebanyak 74,07\% peserta didik memperoleh nilai dengan kategori tinggi, dan sebanyak $14,82 \%$ peserta didik memperoleh nilai dengan kategori cukup. Data kemampuan pemecahan masalah pada kelompok kontrol sebelum pembelajaran yaitu sebanyak $9,68 \%$ peserta didik memperoleh nilai dengan kategori rendah, dan 90,32\% peserta didik memperoleh nilai dengan kategori sangat rendah, sedangkan data kemampuan pemecahan masalah setelah proses pembelajaran berlangsung dengan model PS pada materi hidrolisis garam yaitu sebanyak 3,23\% peserta didik memperoleh nilai dengan kriteria sangat tinggi, sebanyak $16,13 \%$ peserta didik memperoleh nilai dengan kategori tinggi, dan sebanyak 54,84\% peserta didik memperoleh nilai dengan kategori cukup, $22,58 \%$ peserta didik memperoleh nilai dengan kategori rendah, dan 3,22\% peserta didik memperoleh nilai dengan kategori sangat rendah.

Hasil analisis data kemampuan pemecahan masalah pada kelompok eksperimen diperoleh rata-rata pretest 30,836 dengan kategori rendah dan rata-rata posttest 74,394 dengan kategori tinggi, dengan pencapaian peningkatan berkategori sedang dilihat dari nilai N-Gain sebesar 0,632. Hasil analisis kemampuan pemecahan masalah pada kelompok kontrol diperoleh rata-rata pretest 34,468 dengan kategori rendah dan rata-rata posttest 60,948 dengan kategori cukup, dengan pencapaian peningkatan berkategori sedang dilihat dari nilai N-Gain sebesar 0,403. Hasil yang diperoleh pada kedua kelomppok tersebut seperti disajikan pada Tabel 4 di bawah ini. 
Tabel 4. Hasil Analisis Data Kemampuan Pemecahan Masalah Peserta didik

\begin{tabular}{lcccccc}
\hline $\begin{array}{c}\text { Kelompok } \\
\text { Peserta } \\
\text { didik }\end{array}$ & $\begin{array}{c}\text { Rata-rata } \\
\text { pretest }\end{array}$ & Kategori & $\begin{array}{c}\text { Rata-rata } \\
\text { posttest }\end{array}$ & Kategori & $\begin{array}{c}\text { Rata-rata } \\
\text { N-Gain }\end{array}$ & Kategori \\
\hline Eksperimen & 30,836 & Rendah & 74,394 & Tinggi & 0,632 & Sedang \\
Kontrol & 34,468 & Rendah & 60,948 & Cukup & 0,403 & Sedang \\
\hline
\end{tabular}

Data pada Tabel 4 di atas menunjukkan peningkatan kemampuan pemecahan masalah yang lebih baik pada kelompok eksperimen dibandingkan dengan kelompok kontrol, hal ini tampak dari perbedaan pencapaian peningkatan rata-rata dan kategori nilai sebelum (pretest) dan setelah (posttest) pembelajaran yaitu 30,836 kategori rendah menjadi 74,394 kategori tinggi pada kelompok eksperimen, 34,468 kategori rendah menjadi 60,948 kategori cukup pada kelompok kontrol. Hasil ini sejalan dengan penelitian yang dilakukan oleh Mahardika et al (2012) bahwa model CPS dapat meningkatkan kemampuan pemecahan masalah selama proses pembelajaran sebesar 82,71 dengan kategori tinggi. Siswadi et al (2014) model pembelajaran CPS berpengaruh terhadap peningkatan hasil belajar peserta didik sebesar 30\%. Satriani \& Wahyuddin (2019) menyatakan bahwa implementasi model CPS dapat meningkatkan kemampuan pemecahan masalah dari 63,03 (kategori cukup) menjadi 77,72 kategori tinggi. Model CPS juga dapat meningkatkan kemampuan pemecahan masalah peserta didik dari 71,69 dengan kategori sedang (ketuntasan belajar secara klasikal 60\%) menjadi 86,94 kategori tinggi (ketuntasan belajar klasikal 88,57\%).

Secara statistika data kemampuan pemecahan masalah untuk data pretest dan posttest pada kedua kelompok pembelajaran dinyatakan normal (sig.>0,05) setelah melalui uji normalitas menggunakan metode Kolmogorov-Smirnov dengan bantuan SPSS 16.0 for windows (Tabel 5), selanjutnya dilakukan analisis data secara statistika menggunakan independent sample t-test berbatuan SPSS 16.0 for windows (hasil analisis pada Tabel 6).

Tabel 5. Uji Normalitas Data Kemampuan Pemecahan Masalah

\begin{tabular}{lllll}
\hline \multicolumn{1}{c}{ Kelas } & \multicolumn{1}{c}{ Tes } & N & Sig. & Normality \\
\hline Eksperimen & Pretest & \multirow{2}{*}{27} & 0,337 & Normal \\
& Posttest & & 0,345 & Normal \\
Kontrol & Pretest & \multirow{2}{*}{31} & 0,701 & Normal \\
& Posttest & & 0,641 & Normal \\
\hline
\end{tabular}

Tabel 6. Analisis Statistika Data Kemampuan Pemecahan Masalah

\begin{tabular}{llcccc}
\hline \multicolumn{1}{c}{ Group } & N & Std. Dev & & Std. Error Mean & $\boldsymbol{P}$ \\
\hline Eksperimen & 27 & 6,789 & 1,306 & 0,000 \\
Kontrol & 31 & 9,235 & 1,658 & \\
\hline
\end{tabular}

Hasil analisis statistika sesuai data pada Tabel 6 menunjukkan bahwa nilai signifikansi untuk perbandingankelompok eksperimen dan kelompok kontrol sebesar $0,000(\mathrm{p}<0,05)$, artinya ada perbedaan peningkatan kemampuan pemecahan masalah yang diperoleh dari perbandingan skor postest pada kedua kelompok, yang disebabkan karena perbedaan perlakuan dalam pembelajaran. Model pembelajarn CPS berpengaruh terhadap kemampuan pemecahan masalah peserta didik sebesar 17,91\% (Hariawan et al., 2014).

Penelitian ini berupaya untuk meningkatkan kemampuan pemecahan masalah pada peserta didik dalam pembelajaran kimia materi hidrolisis garam dengan menggunakan model CPS. Hasil yang diperoleh menunjukkan bahwa model CPS dapat memberikan peningkatan yang lebih baik dibandingkan pembelajaran dengan model PS, dilihat dari 
rata-rata posttest sebesar 74,394 dengan kategori tinggi pada kelompok eksperimen sedangkan pada kelompok kontrol diperoleh rata-rata posttest sebesar 60,948 berkategori cukup. Hasil ini menunjukkan bahwa model CPS dapat memberikan kesempatan yang lebih besar kepada peserta didik untuk lebih memahami konsep dan masalah dengan melibatkan pengetahuan yang dimiliki dalam proses berpikirnya. Model CPS memiliki kelebihan dalam implementasinya yaitu dapat memberikan peserta didik memahami konsep dengan cara menyelesaikan suatu masalah, membuat siswa aktif dalam pembelajaran, mengembangkan kemampuan berpikir dan membuat peserta didik dapat menerapkan pengetahuan yang sudah dimiliki (Totiana et al., 2013). Peserta didik mampu berbagi pengetahuan, berinteraksi, berkolaborasi dalam belajar dan bertukar pikiran serta pengalaman (Laisema, 2013).

Model CPS juga cocok untuk mengembangkan pemikiran kreatif dan keterampilan bekerjasama tingkat tinggi. Proses pemecahan masalah memiliki efek yang tinggi pada pemikiran kreatif peserta didik (Maraviglia \& Kvashny, 2006). Kemampuan pemecahan masalah dapat dilatihkan dalam pembelajaran agar menghasilkan peserta didik yang selalu siap dan terampil dalam menghadapi setiap permasalahan pembelajaran dalam berbagai keadaan dan situasi. Model CPS dinilai efektif dan fleksibel dan dapat disesuaikan untuk memenuhi kebutuhan setiap individu, setiap masalah dan situasi (Laisema, 2013).

Implementasi pembelajaran dengan model PS pada kelompok kontrol juga dapat memberikan peningkatan pada kemampuan pemecahan masalah peserta didik dalam pembelajaran kimia materi hidrolisis garam. Model PS juga menitikberatkan pada aspek kemampuan pemecahan masalah dengan memahami, membuat rencana, melaksanakan perencanaan, dan memeriksa kembali proses pemecahan masalah. Hasil yang diperoleh dari implementasi model ini terhadap kemampuan pemecahan masalah peserta didik mengalami peningkatan dengan rata-rata 60,948 berkategori cukup, dan hasil ini lebih rendah daripada pembelajaran dengan model CPS pada kelompok eksperimen. Implementasi model PS dalam pembelajaran umumnya peserta didik mengalami kesulitan dalam melakukan proses melihat kembali kinerja pemecahan masalah yang telah dilakukan sampai ditemukannya hasil yang benar (Sukaisih \& Muhali, 2014).

\section{Keterampilan Proses Sains Peserta Didik}

Data keterampilan proses sains peserta didik pada kelompok eksperimen dan kontrol dapat dideskripsikan bahwa pada kelompok eksperimen keterampilan proses sains sebelum pembelajaran (pretest) sebanyak 7,41\% peserta didik memperoleh kategori sangat tinggi, 25,93\% memperoleh kategori tinggi, 14,81\% memperoleh kategori cukup, 40,74\% memperoleh kategori rendah, dan 11,11\% memperoleh kategori sangat rendah, sedangkan keterampilan proses sains setelah pembelajaran (posttest) sebanyak 51,85\% peserta didik berkategori sangat tinggi, 37,04\% dengan kategori tinggi, dan 11,11\% kategori cukup. Keterampilan proses sains peserta didik pada kelompok kontrol sebelum pembelajaran (pretest) sebanyak 25,81\% peserta didik memperoleh kategori sangat tinggi, 32,26\% memperoleh kategori tinggi, 12,90\% memperoleh kategori cukup, 25,81\% memperoleh kategori rendah, dan 3,23\% memperoleh kategori sangat rendah, sedangkan keterampilan proses sains setelah pembelajaran (posttest) sebanyak 12,90\% peserta didik berkategori sangat tinggi, 67,74\% dengan kategori tinggi, dan 19,35\% kategori cukup.

Analisis data keterampilan proses sains peserta didik pada kedua kelompok secara rata-rata dan kategori, serta perolehan nilai rata-rata $\mathrm{N}$-Gain disajikan pada Tabel 7 berikut ini. 
Tabel 7. Nilai Rata-rata Keterampilan Proses Sains, N-Gain dan Kategori Sebelum (Pretest) dan Setelah (Posttest) Pembelajaran

\begin{tabular}{lcccccc}
\hline Kelompok & $\begin{array}{c}\text { Rata-rata } \\
\text { pretest }\end{array}$ & Kategori & $\begin{array}{c}\text { Rata-rata } \\
\text { posttest }\end{array}$ & Kategori & $\begin{array}{c}\text { Rata-rata } \\
\text { N-Gain }\end{array}$ & Kategori \\
\hline Eksperimen & 59,226 & Cukup & 79,389 & Tinggi & 0,369 & Sedang \\
Kontrol & 67,355 & Tinggi & 72,794 & Tinggi & 0,094 & Rendah \\
\hline
\end{tabular}

Berdasarkan data pada Tabel 7 tersebut menunjukkan bahwa keterampilan proses sains peserta didik yang dibelajarkan dengan model CPS mencapai rata-rata lebih baik dilihat dari rata-rata posttest 79,389 dari pada dengan dibelajarkan menggunakan model PS dengan capaian rata-rata posttest 72,794 . Peningkatan yang dicapai pada kedua kelompok, pada kelompok eksperimen (model CPS) mengalami peningkatan dari kategori cukup menjadi kategori tinggi, dengan capaian rata-rata $\mathrm{N}-\mathrm{Gain}$ 0,369 kategori sedang. Kelompok kontrol (model PS) keterampilan proses sains peserta didik tidak mengalami peningkatan kategori dari pretest-postest, pencapaian rata-rata $\mathrm{N}$-gain sebesar 0,094 dengan kategori rendah. Hal ini menunjukkan bahwa pembelajaran dengan model CPS memberikan peningkatan keterampilan proses sains yang lebih baik kepada peserta didik dibandingkan dengan pembelajaran dengan model PS. Terdapat peningkatan keterampilan proses sains peserta didik dengan rata-rata nilai $\mathrm{N}$-gain sebesar 0,63 , persentase keterampilan proses sains dengan kriteria sangat baik $61,92 \%$, kategori baik 28,52\%, dan kategori cukup 9,52\% (Fitriah, 2013). Dipihak lain, diketahui bahwa implementasi model CPS dalam pembelajaran dapat menghasilkan pencapaian keterampilan proses sains peserta didik dengan persentase skor 75,34\% dengan kategori baik (Bakar et al., 2018).

Secara statistika data keterampilan proses sains untuk data pretest dan posttest pada kedua kelompok pembelajaran dinyatakan normal (sig.>0,05) setelah melalui uji normalitas menggunakan metode Kolmogorov-Smirnov dengan bantuan SPSS 16.0 for windows (Tabel 8), selanjutnya dilakukan analisis data secara statistika menggunakan independent sample t-test berbatuan SPSS 16.0 for windows (hasil analisis pada Tabel 9).

Tabel 8. Uji Normalitas Data Keterampilan Proses Sains

\begin{tabular}{lllcc}
\hline \multicolumn{1}{c}{ Kelas } & \multicolumn{1}{c}{ Tes } & N & Sig. & Normality \\
\hline Eksperimen & Pretest & \multirow{2}{*}{27} & 0,702 & Normal \\
\multirow{3}{*}{ Kontrol } & Posttest & & 0,923 & Normal \\
& Pretest & \multirow{2}{*}{31} & 0,748 & Normal \\
& Posttest & & 0,875 & Normal \\
\hline
\end{tabular}

Tabel 9. Analisis Statistika Data Keterampilan Proses Sains

\begin{tabular}{llllc}
\hline \multicolumn{1}{c}{ Group } & $\mathbf{N}$ & Std. Dev & \multicolumn{1}{c}{ Std. Error Mean } & $\boldsymbol{P}$ \\
\hline Eksperimen & 27 & 16,21 & 3,119 & \multirow{2}{*}{0,000} \\
Kontrol & 31 & 14,45 & 2,596 & \\
\hline
\end{tabular}

Hasil analisis statistika sesuai data pada Tabel 9 menunjukkan bahwa perbandingan nilai signifikansi untuk kelompok eksperimen dan kelompok kontrol sebesar 0,000 $(p<0,05)$, artinya ada perbedaan peningkatan keterampilan proses sains yang diperoleh berdasarkan perbandingan nilai postest pada kedua kelompok. Model PS secara signifikan dapat meningkatkan keterampilan proses sains pada materi larutan elektrolit dan non elektrolit yang ditunjukkan dengan nilai $\mathrm{N}$-gain yang lebih tinggi pada kelompok eksperimen dari pada kelompok control (Kadaritna, 2014). Hasil penelitian lain menunjukkan bahwa implementasi model CPS efektif terhadap peningkatan keterampilan proses sains peserta didik (Sumarli et al., 2018). 
Implementasi model CPS pada penelitian ini juga bertujuan untuk meningkatkan keterampilan proses sains peserta didik pada pembelajaran kimia khususnya materi hidrolisis garam. Hasil penelitian menunjukkan bahwa peningkatan keterampilan proses sains pada peserta didik lebih baik pada kelompok eksperimen yang dibelajarkan dengan model CPS dibandingkan dengan kelompok kontrol yang dibelajarkan dengan model PS. Peningkatan rata-rata dan kategori hasil pretest kelompok eksperimen 59,226 dengan kategori cukup menjadi 79,389 dengan kategori tinggi pada hasil posttest, sedangkan kelompok kontrol pada hasil pretest dengan rata-rata 69,355 berkategori tinggi meningkat menjadi rata-rata 72,794 juga kategori tinggi pada hasil posttest.

Hasil tersebut mengindikasikan bahwa model CPS memberikan penguatan keterampilan proses pada peserta didik sehingga lebih terpusat pada pengajaran dan pemecahan masalah. Ketika dihadapkan dengan suatu pertanyaan, peserta didik dapat memecahkan masalah melalui serangkaian keterampilan proses sains baik aspek keterampilan dasar, mengolah/memproses, dan menginvestigasi. Model CPS dalam implementasinya membelajarkan peserta didik untuk mengklarifikasi masalah, mengumpulkan data, mencari solusi pemecahan masalah, mengungkapkan pendapat, evaluasi dan pemilihan dan implementasi (Doak et al., 2013).

\section{Kesadaran Metakognisi Peserta Didik}

Data kersadaran metakognisi peserta didik pada kedua kelompok dapat dideskripsikan bahwa pada kelompok eksperimen sebelum pembelajaran diperoleh sebanyak 7,41\% peserta didik memiliki kesadaran metakognisi berkategori tinggi, 51,85\% berkategori cukup, dan 40,74\% berkategori rendah, sedangkan setelah pembelajaran dengan model CPS diperoleh sebanyak 70,37\% peserta didik berkategori sangat tinggi, $25,93 \%$ berkategori tinggi, dan 3,70\% berkategori cukup. Data kesadaran metakognisi peserta didik pada kelompok kontrol pembelajaran sebanyak 7,41\% berkategori tinggi, sebanyak 70,37\% berkategori cukup, 37,04\% berkategori rendah, sedangkan kesadaran metakognisi setelah pembelajaran dengan model PS diperoleh sebanyak $44,44 \%$ berkategori sangat tinggi, 59,26\% berkategori tinggi, dan 11,11\% berkategori cukup.

Analisis data kesadaran metakognisi peserta didik pada kedua kelompok secara ratarata dan kategori, serta perolehan nilai rata-rata N-Gain disajikan pada Tabel 10 berikut ini.

Tabel 10. Data Rata-rata dan Kategori serta N-Gain Kesadaran Metakognisi Peserta Didik pada Kelompok Eksperimen dan Kontrol Sebelum dan Setelah Pembelajaran

\begin{tabular}{lcccccc}
\hline Kelompok & $\begin{array}{c}\text { Rata-rata } \\
\text { pretest }\end{array}$ & Kategori & $\begin{array}{c}\text { Rata-rata } \\
\text { posttest }\end{array}$ & Kategori & $\begin{array}{c}\text { Rata-rata } \\
\text { N-Gain }\end{array}$ & Kategori \\
\hline Eksperimen & 57,009 & Rendah & 80,500 & Sangat Tinggi & 0,532 & Sedang \\
Kontrol & 57,226 & Rendah & 77,976 & Tinggi & 0,474 & Sedang \\
\hline
\end{tabular}

Berdasarkan data pada Tabel 10 tersebut dapat dijelaskan bahwa pada kelompok eksperimen, kesadaran metakognisi peserta didik mencapai kategori sangat tinggi dengan rata-rata 80,500 setelah dibelajarkan dengan model CPS pada materi hidrolisis garam.

Pembelajaran pada kelompok kontrol mengalami peningkatan kesadaran metakognisi dengan rata-rata 77,976 kategori tinggi setelah dibelajarkan dengan model PS. Walaupun demikian, dari perolehan rata-rata N-Gain pada kedua kelompok mencapai kategori sedang. Secara statistic, data kesadaran metakognisi untuk data pretest dan posttest pada kedua kelompok pembelajaran dinyatakan normal $($ sig. $>0,05)$ setelah melalui uji normalitas menggunakan metode Kolmogorov-Smirnov dengan bantuan SPSS 16.0 for windows (Tabel 11), selanjutnya dilakukan analisis data secara statistika 
menggunakan independent sample t-test berbatuan SPSS 16.0 for windows (hasil analisis pada Tabel 12).

Tabel 11. Uji Normalitas Data Kesadaran Metakognisi

\begin{tabular}{llccc}
\hline \multicolumn{1}{c}{ Kelas } & \multicolumn{1}{c}{ Tes } & N & Sig. & Normality \\
\hline Eksperimen & Pretest & 27 & 0,568 & Normal \\
& Posttest & & 0,069 & Normal \\
Kontrol & Pretest & \multirow{2}{*}{31} & 0,305 & Normal \\
& Posttest & & 0,267 & Normal \\
\hline
\end{tabular}

Tabel 12. Analisis Statistika Data Kesadaran Metakognisi

\begin{tabular}{llllr}
\hline \multicolumn{1}{c}{ Group } & N & Std. Dev & Std. Error Mean & $\boldsymbol{P}$ \\
\hline Eksperimen & 27 & 9,839 & 1,893 & 0,000 \\
Kontrol & 31 & 8,734 & 1,568 & 0,000 \\
\hline
\end{tabular}

Hasil analisis statistika sesuai data pada Tabel 12 menunjukkan bahwa perbandingan nilai signifikansi untuk kelompok eksperimen dan kelompok kontrol sebesar $0,000(p<0,05)$, artinya ada perbedaan peningkatan kesadaran metakognisi peserta didik yang diperoleh dari nilai postest pada kedua kelompok perlakuan. Proses internalisasi sangat penting dalam pembelajaran untuk dapat melatih peserta didik dalam mempelajari, memahami dan mengaplikasikan konsep secara lebih mendalam dalam kegiatan penyelesaian masalah yang reflektif (Muhali, 2018).

Pembelajaran pada kelompok kontrol yang dibelajarkan dengan model PS mengalami peningkatan kesadaran metakognisi dengan kategori tinggi dengan rata-rata 77,976 . Hal ini menunjukkan bahwa model PS membelajarkan peserta didik untuk dapat mengetahui dan memahami masalah dengan baik, membuat prosedur penyelesaian masalah, melaksanakan prosedur penyelesaian masalah dan melihat kembali proses penyelesaian masalah. Kegiatan peserta didik untuk melihat kembali proses penyelesaian masalah merupakan kegiatan yang menghendaki peserta didik merefleksikan pekerjaanya untuk dapat memperoleh penyelesaian masalah dengan benar.

\section{KESIMPULAN}

Berdasarkan hasil penelitian maka dapat disimpulkan bahwa implementasi model creative problem solving dapat meningkatkan kemampuan pemecahan masalah, keterampilan proses sains, dan kesadaran metakognisi peserta didik pada pembelajaran kimia materi hidrolisis garam. Hal ini dapat dilihat dari peningkatan: (1) kemampuan pemecahan masalah dari rata-rata 30,836 berkategori rendah menjadi 74,394 berkategori tinggi ( $\mathrm{N}$-gain $=0,632$ dengan kategori sedang), (2) keterampilan proses sains peserta didik dari rata-rata 59,226 berkategori cukup menjadi 79,389 berkategori tinggi $(\mathrm{N}$-gain $=0,369$ berkategori sedang), dan (3) kesadaran metakognisi peserta didik dari rata-rata 57,009 berkategori rendah menjadi rata-rata 80,500 berkategori sangat tinggi $(\mathrm{N}-\mathrm{Gain}=0,532$ dengan kategori sedang).

\section{REKOMENDASI}

Rekomendasi dari penelitian ini yaitu implementasi model creative problem solving dalam pembelajaran untuk meningkatkan kemampuan pemecahan masalah, keterampilan proses sains, dan kesadaran metakognisi peserta didik dapat dilakukan dengan baik dengan lebih memperhatikan proses pembelajaran pada tahap brainstorming, evaluasi dan pemilihan karena berhubungan dengan kemampuan peserta didik dalam menemukan, mengungkap, dan menentukan strategi yang cocok sebagai solusi penyelesaian masalah yang benar. 


\section{DAFTAR PUSTAKA}

Arikunto, S. (2013). Dasar-dasar Evaluasi Pendidikan (edisi 2). Bumi Aksara. https://ecampus-fip.umj.ac.id/pustaka_umj/main/item/14939

Bakar, A., Nurjanah, S., \& Fuldiaratman, F. (2018). Analisis Keterlaksanaan Model Pembelajaran Creative Problem Solving (CPS) dan Pengaruhnya terhadap Keterampilan Proses Sains Siswa pada Materi Asam Basa Kelas XI IPA SMAN 10 Kota Jambi. Journal of The Indonesian Society of Integrated Chemistry, 10(1), 41-48. https://doi.org/10.22437/jisic.v10i1.5309

Doak, C. K., Jambura, S. M., Knittel, J. A., \& Rule, A. C. (2013). Analyzing the Creative Problem-Solving Process: Inventing a Product from a Given Recyclable Item. Creative Education, 04(09), 592-604. https://doi.org/10.4236/ce.2013.49085

Effendi, A. (2016). Implementasi model creative problem solving untuk meningkatkan kemampuan metakognitif berdasarkan kemampuan awal matematis siswa. JPPM (Jurnal Penelitian dan Pembelajaran Matematika), 9(2), Article 2. https://doi.org/10.30870/jppm.v9i2.994

Fitriah, E. (2013). Implementasi model creative problem solving bervisi SETS dalam meningkatkan keterampilan proses sains dan kreativitas siswa SMA berbasis pesantren. Scientiae Educatia: Jurnal Pendidikan Sains, 2(2), 19-36. https://doi.org/10.24235/sc.educatia.v2i2.516

Hariawan, H., Kamaluddin, K., \& Wahyono, U. (2014). Pengaruh Model Pembelajaran Creative Problem Solving Terhadap Kemampuan Memecahkan Masalah Fisika Pada Siswa Kelas XI SMA Negeri 4 Palu. JPFT (Jurnal Pendidikan Fisika Tadulako Online), 1(2), 48-54.

Jefriadi, Sahputra, R., \& Erlina. (2014). Deskripsi kemampuan representasi mikroskopik dan simbolik siswa SMA Negeri di Kabupaten Sambas materi hidrolisis garam. Jurnal Pendidikan Dan Pembelajaran Khatulistiwa, 3(1), Article 1. https://jurnal.untan.ac.id/index.php/jpdpb/article/view/4431

Kadaritna, N. (2014). Model problem solving efektif dalam meningkatkan keterampilan proses sains siswa MAN 1 Bandar Lampung. Jurnal Pendidikan MIPA (Old), 15(1), Article 1. http://jurnal.fkip.unila.ac.id/index.php/jpm/article/view/5490

Laisema, S. (2013). Development of a Collaborative Learning with Creative ProblemSolving Process Model in Ubiquitous Learning Environment. International Journal of E-Education, e-Business, e-Management and e-Learning. https://doi.org/10.7763/IJEEEE.2013.V3.201

Maraviglia, F. L., \& Kvashny, A. (2006). Managing Virtual Changes-A Guide to Creative Problem Solving for the Design Professions. AuthorHouse.

Muhali, M. (2018). Pengembangan Model Pembelajaran Reflektif-Metakognitif untuk Meningkatkan Kemampuan Metakognisi Siswa SMA (Developement of ReflectiveMetacognitive Learning Model to Improve High School Students' Metacognition Ability).

Muhali, M., Yuanita, L., \& Muslimin, L. (2019). The Validity and Effectiveness of the Reflective-Metacognitive Learning Model to Improve Students' Metacognition Ability in Indonesia. Malaysian Journal of Learning and Instruction, 16(Number 2). https://doi.org/10.32890/mjli2019.16.2.2

Polya, G. (1957). How To Solve It. Princeton University Press.

Prayogi, S., Asy'ari, M., Sukaisih, R., \& Hidayat, S. (2014). Mengembangkan keterampilan proses sains dalam Pembelajaran. Duta Pustaka Ilmu.

Sagita, I., Medriati, R., \& Purwanto, A. (2018). Penerapan Creative Problem Solving Model untuk Meningkatkan Kemampuan Pemecahan Masalah Fisika Siswa Kelas 
XI MIA 4 MAN 2 Kota Bengkulu. Jumal Kumparan Fisika, 1(3), 1-6. https://doi.org/10.33369/jkf.1.3.1-6

Satriani, S., \& Wahyuddin, W. (2019). Implementasi Model Pembelajaran Creative Problem Solving (CPS) Untuk Meningkatkan Kemampuan Pemecahan Masalah Mahasiswa. Jurnal Derivat: Jurnal Matematika Dan Pendidikan Matematika, 5(1), 6981. https://doi.org/10.31316/j.derivat.v5i1.149

Schraw, G., \& Dennison, R. S. (1994). Assessing Metacognitive Awareness. Contemporary Educational Psychology, 19(4), 460-475. https://doi.org/10.1006/ceps.1994.1033

Shoimin, A. (2014). Model pembelajaran inovatif dalam kurikulum 2013. Ar-Ruz Media.

Siswadi, I. B. I. P., Ida Bagus Gede Surya Abadi, S., \& Drs. I Gusti Agung Oka Negara, S. P. M. K. (2014). Pengaruh model pembelajaran creative problem solving (CPS) berbantuan media grafis terhadap hasil belajar IPA siswa kelas V SD Gugus VI Pangeran Diponogoro Denpasar Barat tahun ajaran 2013/2014. MIMBAR PGSD Undiksha, 2(1), Article 1. https://doi.org/10.23887/jjpgsd.v2i1.2538

Sukaisih, R., \& Muhali, M. (2014). Meningkatkan Kesadaran Metakognitif dan Hasil Belajar Siswa Melalui Penerapan Pembelajaran Problem Solving. Prisma Sains: Jurnal Pengkajian Ilmu Dan Pembelajaran Matematika Dan IPA IKIP Mataram, 2(1), 71. https://doi.org/10.33394/j-ps.v2i1.803

Sukaisih, R., Muhali, M., \& Asy'ari, M. (2020). Meningkatkan keterampilan metakognisi dan berpikir kritis siswa melalui pembelajaran model pemecahan masalah dengan strategi konflik-kognitif. Empiricism Journal, 1(1), 37-50. https://doi.org/10.36312/ej.v1i1.329

Sumarli, S., Nugroho, S. E., \& Yulianti, I. (2018). Keefektifan Model Pembelajaran Creative Problem Solving Berpendekatan Inquiry terhadap Keterampilan Proses Sains Siswa. Physics Communication, 2(1), 63-69. https://doi.org/10.15294/physcomm.v2i1.11540

Suyatno. (2009). Menjelajah pembelajaran inovatif. Masmedia Buana Pustaka.

Totiana, F., V.h, E. S., \& Redjeki, T. (2013). Efektivitas model pembelajaran creative problem solving yang dilengkapi media pembelajaran laboratorium virtual terhadap prestasi belajar siswa pada materi pokok koloid kelas XI IPA semester genap SMAN 1 Karang Anyar Tahun Pelajaran 2011/2012. Jurnal Pendidikan Kimia. Jurnal Pendidikan Kimia, 1(1), Article 1. https://jurnal.fkip.uns.ac.id/index.php/kimia/article/view/1156 